\title{
Paediatric Cushing's disease: Epidemiology, pathogenesis, clinical management and outcome
}

\author{
Rosario Ferrigno ${ }^{1}$ (D) - Valeria Hasenmajer ${ }^{2}$ (D) $\cdot$ Silvana Caiulo $^{3} \cdot$ Marianna Minnetti $^{2}$ (D) Paola Mazzotta $^{2} \cdot$

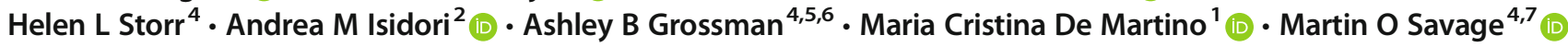

Accepted: 5 January 2021 / Published online: 30 January 2021

(C) The Author(s) 2021

\begin{abstract}
Cushing's disease $(\mathrm{CD})$ is rare in paediatric practice but requires prompt investigation, diagnosis and therapy to prevent longterm complications. Key presenting features are a change in facial appearance, weight gain, growth failure, virilization, disturbed puberty and psychological disturbance. Close consultation with an adult endocrinology department is recommended regarding diagnosis and therapy. The incidence of $\mathrm{CD}$, a form of ACTH-dependent Cushing's syndrome (CS), is equal to approximately $5 \%$ of that seen in adults. The majority of ACTH-secreting adenomas are monoclonal and sporadic, although recent studies of pituitary tumours have shown links to several deubiquitination gene defects. Diagnosis requires confirmation of hypercortisolism followed by demonstration of ACTH-dependence. Identification of the corticotroph adenoma by pituitary MRI and/or bilateral inferior petrosal sampling for ACTH may contribute to localisation before pituitary surgery. Transsphenoidal surgery (TSS) with selective microadenomectomy is first-line therapy, followed by external pituitary irradiation if surgery is not curative. Medical therapy to suppress adrenal steroid synthesis is effective in the short-term and bilateral adrenalectomy should be considered in cases unfit for TSS or radiotherapy or when urgent remission is needed after unsuccessful surgery. TSS induces remission of hypercortisolism and improvement of symptoms in $70-100 \%$ of cases, particularly when performed by a surgeon with experience in children. Post-TSS complications include pituitary hormone deficiencies, sub-optimal catch-up growth, and persisting excess of BMI. Recurrence of hypercortisolism following remission is recognised but infrequent, being less common than in adult CD patients. With experienced specialist medical and surgical care, the overall prognosis is good. Early referral to an experienced endocrine centre is advised.
\end{abstract}

Keywords Hypercortisolism $\cdot$ Paediatric $\cdot$ Cushing's $\cdot$ Cortisol $\cdot$ Pituitary

Rosario Ferrigno, Valeria Hasenmajer, Silvana Caiulo, Marianna Minnetti and Paola Mazzotta contributed equally to this work.

Martin O Savage

m.o.savage@qmul.ac.uk

1 Dipartimento di Medicina Clinica e Chirurgia, Federico II University, Naples, Italy

2 Department of Experimental Medicine, Sapienza University of Rome, Rome, Italy

3 Primary care Paediatrician, Local Health Unit of Brindisi, Brindisi, Italy

4 Centre for Endocrinology, William Harvey Research Institute, Barts and the London School of Medicine \& Dentistry, London, UK

5 Royal Free Hospital ENETs Centre of Excellence, London, UK

6 Oxford Centre for Diabetes, Endocrinology and Metabolism, University of Oxford, Oxford, UK

7 Centre for Endocrinology, William Harvey Research Institute, Charterhouse Square, London EC1M 6BQ, UK

\section{Introduction}

Cushing's disease (CD), defined as hypercortisolism caused by excess adrenocorticotropic Hormone (ACTH) secretion by a pituitary corticotroph adenoma [1], presents rarely in the paediatric age range. However, this serious disorder requires early diagnosis and specialised management because the morbidity related to chronic hypercortisolism in paediatric patients is considerable. Its rarity, having an incidence approximately $5 \%$ of that seen in adults [2], has resulted in paediatric endocrinologists having limited experience in diagnosis or therapy in this essentially adult disorder. Although the principles of investigation and therapy should be conducted in paediatric facilities and are based on adult experience, management of paediatric $\mathrm{CD}$ by paediatricians in isolation is not recommended. The active cooperation and discussion with adult endocrinologists, including consultation on invasive radiological and neurosurgical techniques, is beneficial to patient care. 
In terms of aetiology, new genetic findings related to mutations of deubiquitinase genes involved in pituitary adenoma growth and secretion of ACTH have questioned the traditional view that corticotroph adenomas are essentially sporadic and monoclonal in origin [3]. The presenting features of paediatric CD resemble those in adults; however, some notable differences have been recognised such as male predominance in prepubertal patients, disturbance of growth and puberty, predominance of microadenomas, poor prediction by pituitary MRI of tumour visibility and, in terms of therapy, more rapid control of hypercortisolism following pituitary radiotherapy (RT) [4].

These and other features of the epidemiology, pathogenesis, diagnosis, therapeutic approach and long-term outcome will be discussed in this review. The authors comprise both paediatric and adult endocrinologists, consistent with our message of close collaboration between the two disciplines for the optimal care of patients with paediatric CD.

\section{Epidemiology}

Endogenous Cushing's syndrome (CS) is rare in children and adolescents and is relatively uncommon in adults, with an incidence of $0.7-2.4$ per million in the general population per year $[1,5]$. Two studies from Denmark and Spain reported incidences of endogenous CS as 2 and 2.4 cases respectively per million inhabitants per year $[6,7]$. The commonest cause of endogenous CS in all age groups is Cushing's disease (CD). At all ages, corticotroph microadenomas are the commonest cause of CD [1]. Corticotroph macroadenomas occur in only $\sim 10 \%$ of adult CD cases and are even rarer in children $[4,8]$.

The annual incidence of CD in Sweden during the years 1987 to 2013 was reported as $1.6(1.4-1.8)$ cases per million. Mean $( \pm \mathrm{SD})$ age at diagnosis was $43 \pm 16$ years. Of 534 patients, $32(6 \%)$ were younger than 18 years at diagnosis: $17(53 \%)$ girls and $15(47 \%)$ boys [2]. CD accounts for $\sim 70 \%$ of adult-onset $[1,9]$ and $75-80 \%$ of paediatriconset endogenous CS $[10,11]$. An estimated 1 to 1.5 per million children are affected each year by CS; of those 75$80 \%$ are caused by an ACTH-secreting pituitary tumour (CD) [12]. Corticotroph adenomas are reported to constitute $54.8 \%$ of all pituitary adenomas in the ages $0-11$ years and $29.44 \%$ in the ages $12-17$ years [13]. In children aged less than 5 years, CD is extremely rare - the most common causes of CS in this age group are adrenocortical adenoma or carcinoma and bilateral adrenal hyperplasia [12]. The mean age of $\mathrm{CD}$ presentation, in several large paediatric series comprising 41-182 children, was 12.314.1 years [14].

\section{Pathogenesis}

The majority of ACTH-secreting adenomas are monoclonal and sporadic [15]. Rarely, CD may occur in the context of a genetic neoplasia syndrome; however the majority of paediatric corticotroph adenomas are not caused by germline genetic defects [16].

\subsection{MEN1 mutations}

Multiple endocrine neoplasia (MEN) 1 is an autosomal dominant disorder characterised by neuroendocrine neoplasia arising mainly in parathyroid glands, pancreatic islet cells, and the anterior pituitary gland. CD can very rarely be part of MEN 1 , due to mutations in the tumour suppressor gene $M E N 1$, which encodes a 610-amino acid protein, menin. Pituitary adenomas occur in 20-50\% of MEN 1 cases, mostly somatotroph or lactotroph in origin, but corticotroph adenomas have rarely been described $[17,18]$. In a cohort of 74 paediatric cases with sporadic $\mathrm{CD}$, genetic screening identified an MEN1 mutation in 1 patient [19]. Additionally, 4 paediatric patients aged 1114 years had CD associated with a family history of genetically-confirmed MEN1 $(n=2)$, clinical features of MEN1 $(n=1)$ or a TSC2 mutation-positive tuberous sclerosis $(n=1)$ [19]. Genotyping demonstrated that the two patients were carriers of their familial MEN1 mutations and of the 4 patients with suspected genetic syndromes and $\mathrm{CD}$, only 2 syndromic patients who had relatives with geneticallyconfirmed MEN 1 syndrome had MEN1 mutations [19].

\subsection{FIPA}

Familial isolated pituitary adenomas (FIPA) is a genetic condition characterised by pituitary adenomas in the absence of other clinical features. In $20 \%$ of FIPA families, mutations in the aryl hydrocarbon receptor-interacting protein $(A I P)$ gene have been identified. However, CD very rarely occurs in FIPA and germline AIP mutations are infrequently found in patients with CD [20]. In 73 paediatric CD cases, only $1(1.4 \%)$ was found to have an AIP mutation [19].

\subsection{Deubiquitinase gene mutations}

\subsubsection{USP8 mutations}

Studies using next generation sequencing on the molecular origin of pituitary adenomas have started to unveil the genetic basis of $\mathrm{CD}$. The most frequent somatic mutations in paediatric $\mathrm{CD}$ have been detected in the USP8 gene that was identified in 31-63\% of corticotroph adenomas [3, 21, 22]. The USP8 gene encodes a deubiquitinase, which regulates the stability of tyrosine kinase receptors, such as the epidermal growth factor receptor (EGFR) [3]. The deubiquitination of 
EGFR prevents its lysosomal degradation, allowing downstream signalling pathways to function in an active state [23]. In a study from the NIH [22], 5 different USP 8 mutations ( 3 missense, 1 frameshift, and $1 \mathrm{in}$-frame deletion) were identified in 13/42 CD patients (31\%), all of them located in exon 14 at the described mutational hotspot, affecting the 14-3-3 binding motif of the protein. Patients with somatic mutations were older [mean $15.1 \pm 2.1$ vs $13.1 \pm 3.6$ years, $P=0.03$ ] Biochemical variables of hypercortisolism and ACTH, as well as tumour size and frequency of invasion of the cavernous sinus, were not different between USP8-mutated and nonmutated subjects. However, patients harbouring somatic USP8 mutations had a higher likelihood of recurrence of CD following transsphenoidal surgery (TSS) compared with patients without mutations ( $46.2 \%$ vs $10.3 \%, P=0.009$ ).

However, the major driver mutations in USP8 wild-type tumours remain elusive. $P O M C$ gene transcription is stimulated by high EGFR levels, with a subsequent increase in plasma ACTH levels [3]. USP8-mutated corticotroph adenoma cells showed higher EGFR transcript and immunoreactivity in human studies [23]. A 16 year old female patient with a de novo germline USP8 mutation with recurrent CD and multiple other medical problems was recently reported [24]. Associated features were developmental delay, dysmorphic features, ichthyosiform hyperkeratosis, chronic lung disease, chronic kidney disease, hyperglycemia, dilated cardiomyopathy with congestive heart failure, and previous history of hyperinsulinism and partial growth hormone (GH) deficiency (GHD). She underwent transsphenoidal surgery and improved, however her $\mathrm{CD}$ recurred [24]. Heterozygous somatic single point mutations have been reported exclusively in $\mathrm{CD}$. The prevalence of USP 8 mutations is higher in female than in male patients with $\mathrm{CD}$, possibly related to oestrogenic action on USP8-mutated cells [21]. Next generation sequencing is facilitating the clarification of the genetic basis of $\mathrm{CD}$. The presence of somatic USP8 driver mutations in a significant portion of corticotroph adenomas represents a novel and unique mechanism leading to ACTH excess. It is possible that inhibition of USP8 or its downstream signalling pathways could represent a new therapeutic approach for the management of CD [25].

\subsubsection{USP48 and BRAF mutations}

Recurrent mutations were reported in an additional deubiquitinase gene, USP48 (predominantly encoding p.M415I or p.M415V) in $21 / 91$ paediatric subjects with corticotroph adenomas and in the BRAF gene (encoding p.V600E) in $15 / 91$ subjects with wild-type USP8 [26]. Similar to USP8 mutants, both USP48 and BRAF mutants enhance the promoter activity and transcription of the $P O M C$ gene providing a potential mechanism for ACTH overproduction [26]. However, these interesting findings require confirmation.

\subsection{CABLES1 mutations}

Another gene related to the pathogenesis of ACTHsecreting adenomas is the CABLES1 (Cdk5 and ABL enzyme substrate 1) gene (18q11.2), which negatively regulates cell cycle progression in response to glucocorticoids. Indeed, the CABLES1 protein expression is lost in around half of corticotroph adenomas [27]. In a cohort of 146 paediatric $\mathrm{CD}$ cases, putative CABLES1 mutations were identified in 2 sporadic female patients [28].

\subsection{Additional mutations in CD patients}

In adults, cyclin $\mathrm{E}$ is over-expressed in corticotroph tumours, and mutations in cyclin E (CCNE), EGFR, CMPtk, and $L A P T M 4 B$ gene have been related to ACTH-secreting tumours [29]; however, these defects are rare in the paediatric CD population [30]. Germline loss-of-function $C D K N 1 B$ gene variants, which are known to cause MEN type 4 in adults, have now been shown to rarely cause sporadic CD without the MEN syndrome in children with $\mathrm{CD}[31]$.

\section{Clinical presentation}

Early recognition of the presenting clinical signs and symptoms of $\mathrm{CD}$ is essential for prompt diagnosis and treatment. The definition of 'paediatric' $C D$ varies in different countries, being $<18$ years in the UK [4], $<18$ years in the USA [32] and $<20$ years in India [33]. Mean ages at diagnosis were 13.1 [34], 12.9 [35], 12.3 [4] and 14.9 years [33]. CD is rare below the age of 5 years. Key clinical findings in paediatric $\mathrm{CD}$ patients are shown in Table 1.

\subsection{Gender and its possible effect on severity}

Gender distribution at the diagnosis of $\mathrm{CD}$ was analysed in 50 patients aged from 6 to 30 years [38]. In 25 of the patients aged 6-18 years, there were 17 males $(68 \%)$ and 8 females (32\%) contrasting with 4 males $(16 \%)$ and 21 females $(84 \%)$ in the 25 subjects aged 18 to 30 years. CD diagnosed before age 18 years occurred predominantly in males, contrasting with female dominance at 18 years or older $(P=0.0003)$. There was also a significant difference $\chi^{2}$ in sex distribution depending on pubertal status $(P=$ 0.0002). In 17 prepubertal CD patients from the same institution, $76 \%$ were male and $24 \%$ female [39]. Male predominance $(89 \%)$ was also seen in prepubertal patients from the NIH [40]. In CD patients presenting during puberty an equal sex incidence (50\% males) was reported [38]. However, a larger series of 102 patients from the NIH showed an equal gender distribution in both prepubertal 
Table 1 Frequency of clinical findings at diagnosis of paediatric Cushing's disease

\begin{tabular}{|c|c|c|c|c|c|}
\hline & Devoe 1997 [34] & Shah 2011 [33] & Storr $2011[4]$ & Lonser 2013 [36] & Guemes 2016 [37] \\
\hline Total number of patients & 42 & 48 & 41 & 200 & 16 \\
\hline Mean age / median age (range) & $\begin{array}{l}13.4 \mathrm{y}^{\mathrm{a}} \\
\quad(6.5-18)\end{array}$ & $\begin{array}{l}14.85^{\mathrm{b}} \pm 2.5 \mathrm{y} \\
\quad(9-19)\end{array}$ & $\begin{array}{c}12.3^{\mathrm{b}} \pm 3.5 \mathrm{y} \\
(5.7-17.8)\end{array}$ & $\begin{array}{c}10.6^{\mathrm{b}} \pm 3.6 \mathrm{y} \\
(4-19)\end{array}$ & $\begin{array}{l}10 \mathrm{y}^{\mathrm{a}} \\
\quad(7-15.5)\end{array}$ \\
\hline \multicolumn{6}{|l|}{ Clinical symptoms and signs (\%) } \\
\hline Weight gain & 92 & 98 & 98 & 93 & 94 \\
\hline Growth retardation & 84 & 83 & 100 & $63^{\mathrm{c}}$ & 63 \\
\hline Short stature & & 56 & & & \\
\hline Facial changes & 46 & 98 & 100 & 63 & \\
\hline Irregular menses (females) & & & & $49^{\mathrm{d}}$ & \\
\hline Osteopaenia & 74 & & & & \\
\hline Fatigue or weakness & 67 & & 61 & 48 & 38 \\
\hline Hirsutism & 46 & & 59 & 56 & 38 \\
\hline Virilization & & & 76 & & \\
\hline Psychiatric disorders & $44^{\mathrm{e}}$ & & & $31^{\mathrm{f}}$ & \\
\hline Mood changes & & 46 & $59^{\mathrm{g}}$ & & $44^{\mathrm{h}}$ \\
\hline Headache & 26 & & 51 & 38 & \\
\hline Striae & 36 & 58 & 49 & 55 & 44 \\
\hline Hypertension & 63 & 71 & 49 & 36 & 50 \\
\hline Acne & 46 & & 44 & 47 & 50 \\
\hline Pubertal delay or arrest & 60 & & & & 19 \\
\hline Early secondary sexual development & & & & & 31 \\
\hline Easy bruising & 28 & 17 & & 25 & 19 \\
\hline Dorsal cervical or supraclavicular fat pad & 28 & & & 69 & \\
\hline Hyperpigmentation & & & & & 13 \\
\hline Acanthosis nigricans & & 75 & & 32 & \\
\hline Muscle weakness & & 48 & & & \\
\hline Sleep disturbances & & & & & 19 \\
\hline Glucose intolerance or diabetes & & 25 & & 7 & \\
\hline Bone fractures & & & & 4 & \\
\hline Hypokalemia & & & & & 6 \\
\hline Infection & & 15 & & & \\
\hline
\end{tabular}

Y, years; ${ }^{\mathrm{a}}$ median age; ${ }^{\mathrm{b}}$ mean age; ${ }^{\mathrm{c}}$ pre-pubertal patients $(n=91)$ showed growth retardation in $85 \%$ of cases, post-pubertal patients $(n=109)$ showed growth retardation in $44 \%$ of cases; ${ }^{\mathrm{d}}$ primary or secondary amenorrhea; ${ }^{\mathrm{e}}$ compulsive behaviour; ${ }^{\mathrm{f}}$ depression, anxiety, mood swings; ${ }^{\mathrm{g}}$ emotional lability/depression; ${ }^{\mathrm{h}}$ mental changes changes/poor school performance

and pubertal subjects [35]. In a series of 183 adult CD patients, aged from 18 to 95 years, there were 144 (77\%) females and $39(23 \%)$ males [4]. The origin of the male predominance before puberty is not currently understood.

Clinical and biochemical abnormalities have been reported to be more severe in adult males with $\mathrm{CD}$, who also presented at a younger age than adult females [41] Storr et al. found found no gender differences in clinical or biochemical features in $50 \mathrm{CD}$ subjects aged 6 to 30 years [38]; however in 102 paediatric patients from NIH, male subjects presented with higher BMI, possibly shorter height and increased plasma $\mathrm{ACTH}$, suggesting a more aggressive form of $\mathrm{CD}$ in boys [35].

\subsection{Facial changes, growth and puberty}

Facial changes, showing the typical Cushingoid appearance, are very common in children with $C D$. Swelling of the face and change in appearance, clearly seen in family photos, were present in 100\% of patients reported by Storr et al. [4], and has been documented in all large paediatric $\mathrm{CD}$ series $[33,36]$. These changes are very distressing for the patients, who may try to lose weight to decrease them. However, they may not be recognised by general practitioners or paediatricians as being pathological, which can result in long intervals between onset of symptoms and diagnosis, reported as 3 years (range $0.25-7$ ) in 50 patients [40] and 2.5 years (range $0.3-6.6$ ) in 43 patients [42]. 
Chronic hypercortisolism causes growth failure, usually associated with abnormal weight gain. Short stature is not always present, being reported in $42 \%$ and $56 \%$ of cases $[32,33]$; however, when height velocity has been calculated, it is subnormal [42]. Bone age is typically delayed at diagnosis [43].The most striking auxological finding is the contrast between height SDS and BMI SDS [33, 40], which was notably absent in subjects with simple obesity, where height SDS is typically above average [44]. A further clinical abnormality related to hypercortisolism and increased adrenal androgens is disturbance of the normal harmony of secondary sexual development. Increased virilisation, shown by advanced Tanner stage of pubic hair growth, is frequently present in prepubertal patients and was positively associated with increased serum androstenedione, DHEA-S and testosterone SDS values and decreased SHBG SDS compared to non-virilised subjects [45]. Hirsutism, acne and purple striae are also common, particularly in older patients. Gonadotrophin secretion is suppressed by hypercortisolism contributing to the imbalance of puberty development with low Tanner stage of breast development and impaired testicular growth combined with advanced stages of pubic hair [45].

\subsection{Psychiatric disturbances, additional features and contrasts between paediatric and adult CD}

Mood changes, depression and emotional lability are common in children with $\mathrm{CD}[36,42]$. More rarely, acute psychosis has been documented which may be an indication for emergency bilateral adrenalectomy [46, 47]. Muscle weakness, osteopaenia, polycythaemia and headache are also common. A comparison between features in paediatric compared with adult CD patients [4] showed that weight gain was present in 99\% of the paediatric subjects (mean BMI SDS at diagnosis 2.7; range $0.0-9.2$ ) in contrast to $65 \%$ of the adult subjects $(P<0.001)$. All paediatric patients reported facial changes compared with $81 \%$ of the adults $(P<0.01)$. Fatigue and emotional lability or depression were commoner in paediatric compared with adult subjects $(P<0.0001$ and $P<0.006$ respectively). Hypertension was the most common additional feature in adult patients $(77 \%)$ but was less common in paediatric patients $(49 \%, P<0.0009)$.

\section{Diagnostic investigations}

Firstly, in paediatric patients with suspected $\mathrm{CD}$, ingestion or administration of exogenous corticosteroids should be promptly excluded by a careful history before biochemical evaluation. At the initial assessment, clinical data on auxological parameters, puberty stage, excessive virilisation and bone age determination should be obtained.

\subsection{Confirmation of hypercortisolism}

Documentation of hypercortisolism is the first step in the diagnostic process. Essentially, three tests that can be used for this purpose: 24-h urinary free cortisol (UFC), late-night sleeping salivary/serum cortisol and dexamethasonesuppression testing. Because none of these tests has $100 \%$ diagnostic accuracy (Table 2) and each test has some limitations, multiple tests are usually needed to confirm hypercortisolism. Recently, a study including paediatric patients (58\% of the cohort less than 18 years) showed that proximal hair cortisol could also be a good marker reflecting hypercortisolism [57], but further studies are needed to confirm the diagnostic value of this technique.

\subsection{Urinary free cortisol excretion}

UFC has been described as a screening test for hypercortisolism in paediatric patients in various studies [34, 36, 37, 48-53]. UFC should always be corrected for body surface area $(\mu \mathrm{g} /$ $\mathrm{m}^{2}$ per $24 \mathrm{~h}$ ). Averaging $24 \mathrm{~h}$ UFC values over two or three days provided better accuracy than a single measurement $[48$, 52]. Nevertheless, the sensitivity of this test analysed in several large series of paediatric patients with CS due to various causes was less than $90 \%$ [34, 48, 52], and therefore 24-h UFC alone is not an ideal screening tool. The main advantages are noninvasiveness and the possibility to collect the 24-h samples at home. However, collection may be difficult in the youngest children. Moreover, a physiological increase in the excretion of UFC can occur in girls during the peri-menarche phase [58]. Evaluation of 17-hydroxysteroid excretion offers no benefit in the workup for paediatric CS [48].

\subsection{Dexamethasone suppression test (DST)}

Diagnosis of hypercortisolism can be made on the basis of failure to suppress serum cortisol to $<1.8 \mu \mathrm{g} / \mathrm{dl}(<50 \mathrm{nmol} / \mathrm{l})$ during a DST. This test has not been evaluated extensively in children and is carried-out essentially by two techniques:

- Overnight DST: $25 \mu \mathrm{g} / \mathrm{kg}$ at $11 \mathrm{p} . \mathrm{m} . /$ midnight (maximum dose $1 \mathrm{mg}$ ) with sampling for serum cortisol at $09.00 \mathrm{~h}$ $[49,53]$;

- Low-dose DST (LDDST): $20-30 \mu \mathrm{g} / \mathrm{kg} /$ day in children $<30 \mathrm{~kg}$ (maximum dose $2 \mathrm{mg}$ /day) divided in $0.5 \mathrm{mg}$ doses every $6 \mathrm{~h}$, given at $09.00,15.00,21.00$ and $03.00 \mathrm{~h}$ for $48 \mathrm{~h}[4,33,37,54]$.

The LDDST has higher sensitivity than the overnight test (Table 2). Increasing the serum cortisol cut-off from 1.8 to $5 \mu \mathrm{g} / \mathrm{dL}$ lowered the sensitivity value [33]. It has been also reported that in the LDDST, cortisol suppression correlated with that during a HDDST $(\mathrm{r}=+0.45, p<0.05)$ with $>30 \%$ 


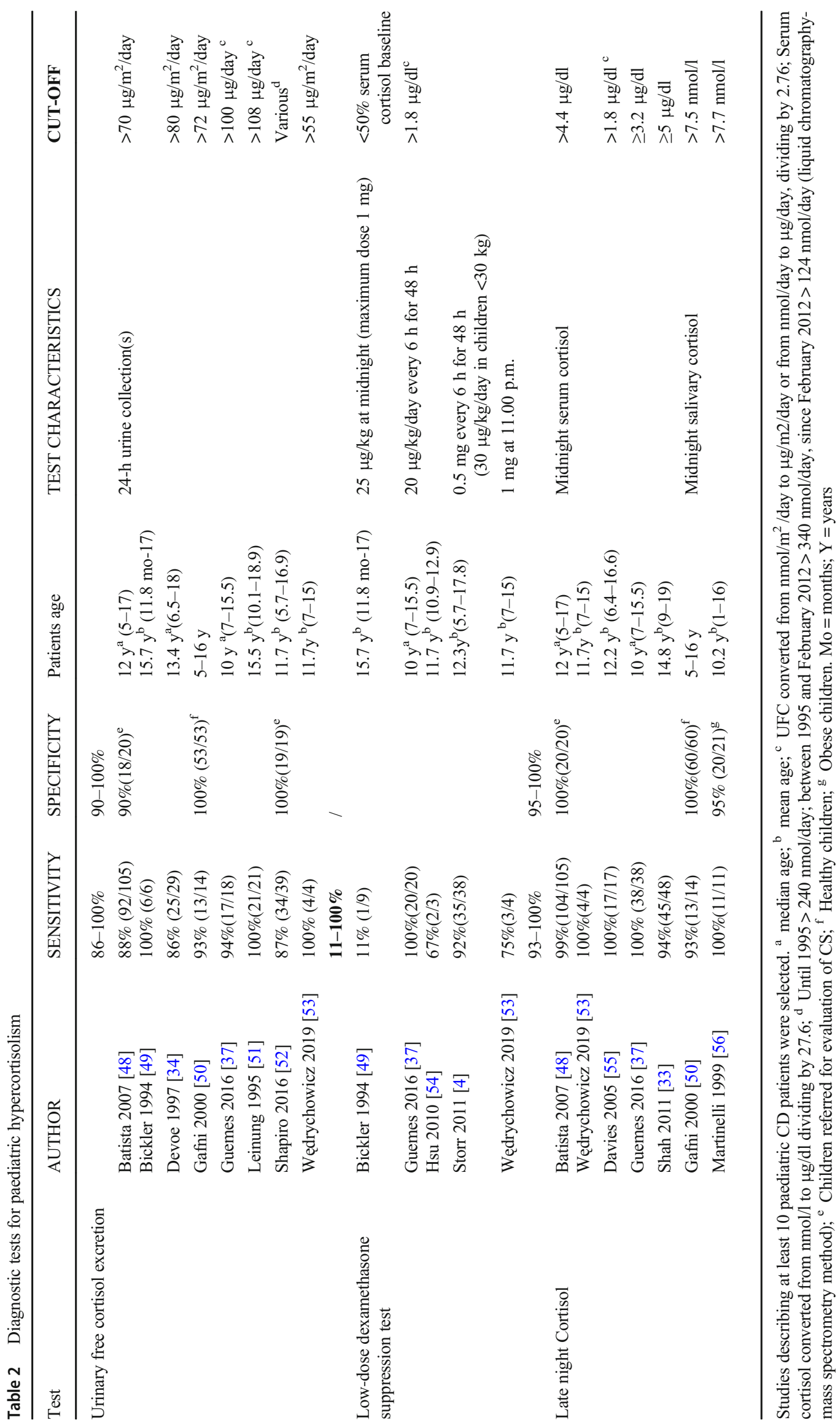


cortisol suppression in the LDDST predicting that change in the HDDST and hence CD [59].

\subsection{Late night cortisol}

Loss of cortisol circadian rhythm is a hallmark of CD. In normal subjects serum cortisol is $<50 \mathrm{nmol} / \mathrm{l}$ during sleep at midnight, as is salivary cortisol. This can be evaluated by serum and salivary late-night sleeping cortisol. Assessment of elevated midnight serum cortisol gives high sensitivity (94-100\%) and specificity (100\%) for hypercortisolism in paediatric CD patients; however, different cut-offs (from 1.8 to $5 \mu \mathrm{g} / \mathrm{dl}$ ) have been proposed (Table 2) [33, 37, 48, 53, 55]. The child should be cannulated before sleeping and not approached for a venipuncture while asleep. Measurement of salivary cortisol late at night represents a non-invasive, easy and cost-effective method. To date, the use of late-night salivary cortisol in children has been evaluated only in two studies comparing paediatric CD patients with healthy children [50] and obese controls [56], showing high sensitivity (93$100 \%)$ and specificity (95-100\%) of this test.

\subsection{Confirmation of pituitary aetiology}

After the diagnosis of hypercortisolism, it is essential to distinguish ACTH-dependent from ACTH-independent CS. Diagnostic investigations are described in Table 3.

\subsection{Basal ACTH}

In paediatric $\mathrm{CD}$, morning plasma ACTH is typically detectable (>5 pg/ml), while patients with primary adrenal diseases showed suppressed ACTH $[39,48]$. The largest series using morning ACTH for differentiate patients with ACTHdependent or independent CS showed that a cut-off of $29 \mathrm{pg} /$ $\mathrm{ml}$ had a sensitivity of $70 \%$ and a specificity of $100 \%$ [48]. Mean plasma ACTH was higher in paediatric patients with ectopic ACTH syndrome (EAS) than with CD, all patients with EAS and $68 \%$ of patients with CD displaying ACTH concentrations above the normal range [61]. Although ACTH assay reliability has improved significantly in recent years, basal ACTH levels may show variability due to the circadian modifications and instability after the sample collection.

\subsection{CRH stimulation test}

To confirm the diagnosis of pituitary-dependent hypercortisolism, a test using intravenous injection of $1 \mu \mathrm{g} / \mathrm{kg} \mathrm{CRH}$ (maximum dose $100 \mu \mathrm{g}$ ) is recommended [4, $37,39,48,53]$. In CD, the ACTH secreting pituitary adenoma is reported to give an exaggerated response to $\mathrm{CRH}$ resulting in an elevated cortisol response $[66,67]$. The most used cutoffs for the differential diagnosis of paediatric CD as opposed to ectopic ACTH are a mean percentage increase of $20 \%$ above baseline for cortisol values (at $30^{\prime}$ and $45^{\prime}$ ) and an increase in the mean ACTH concentrations of at least $35 \%$ over basal values (at $15^{\prime}$ and $30^{\prime}$ ) after $\mathrm{CRH}$ injection [4, 48, 53]. It is interesting that the paediatric population exhibited a more exuberant cortisol response than adults, enhancing the usefulness of the CRH test to differentiate CD from EAS in children $[4,68]$. Finally, desmopressin testing, which also induces an excess ACTH and cortisol response in CD patients, has been used in patients with extremely difficult venous access [68].

\subsection{High-dose dexamethasone suppression test (HDDST)}

In paediatric patients $80-120 \mu \mathrm{g} / \mathrm{kg}$ (maximum dose $8 \mathrm{mg}$ ) of dexamethasone administered in one dose at 11:00 PM or in 4 divided doses, each of $2.0 \mathrm{mg}$, for $48 \mathrm{~h}$ have been described $[4,33,36,37,39,48,49,60,61,63]$. Although a decrease $\geq 50 \%$ in morning cortisol from baseline has been used as cutoff in most of studies describing CD patients [4, 33, 37, 39, 63 ], a decrease $\geq 20 \%$ showed the highest sensitivity $(97.5 \%$ ) and also $100 \%$ specificity to distinguish CD from adrenal tumours [48]. Paediatric patients with EAS, although extremely rare, may show high degrees of cortisol suppression after HDDST, and therefore this test does not accurately exclude EAS $[37,61]$. It should be also noted that in children, HDDST can induce adverse effects, such as transient hypertension or hyperglycaemia [59]. For these reasons and following the diagnostic value of the LDDST, the HDDST is no longer routinely used in some centres [42].

\subsection{Pituitary magnetic resonance imaging (MRI)}

MRI has replaced other radiological techniques for pituitary visualisation and should be obtained after biochemical confirmation of ACTH-dependent CS. Paediatric CD is predominantly associated with corticotroph microadenomas, usually $<6 \mathrm{~mm}$ in diameter, which are typically hypodense on MRI and frequently fail to enhance with gadolinium contrast [36, 39]. Therefore, it is mandatory that pituitary MRI should be performed with thin sections and high resolution at specialist tertiary referral centres for CD. Even so, in the largest and latest series of paediatric CD patients, with more than 20 children described in each, MRI correctly identified a pituitary adenoma in only $16-71 \%$ of patients [4, 33, 36, 62, 65]. Dynamic magnetic resonance can be helpful in diagnosing microadenomas whereas the routine MRI sequences are equivocal [63]. Also, post-contrast spoiled gradient-recalled (SPGR) acquisition seems superior to conventional MRI and dynamic contrast spin echo MRI in paediatric CD patients to detect smaller adenomas [62].

A formal comparison of MRI results in paediatric $(n=39)$ compared with adult $(n=66) \mathrm{CD}$ patients was performed by 


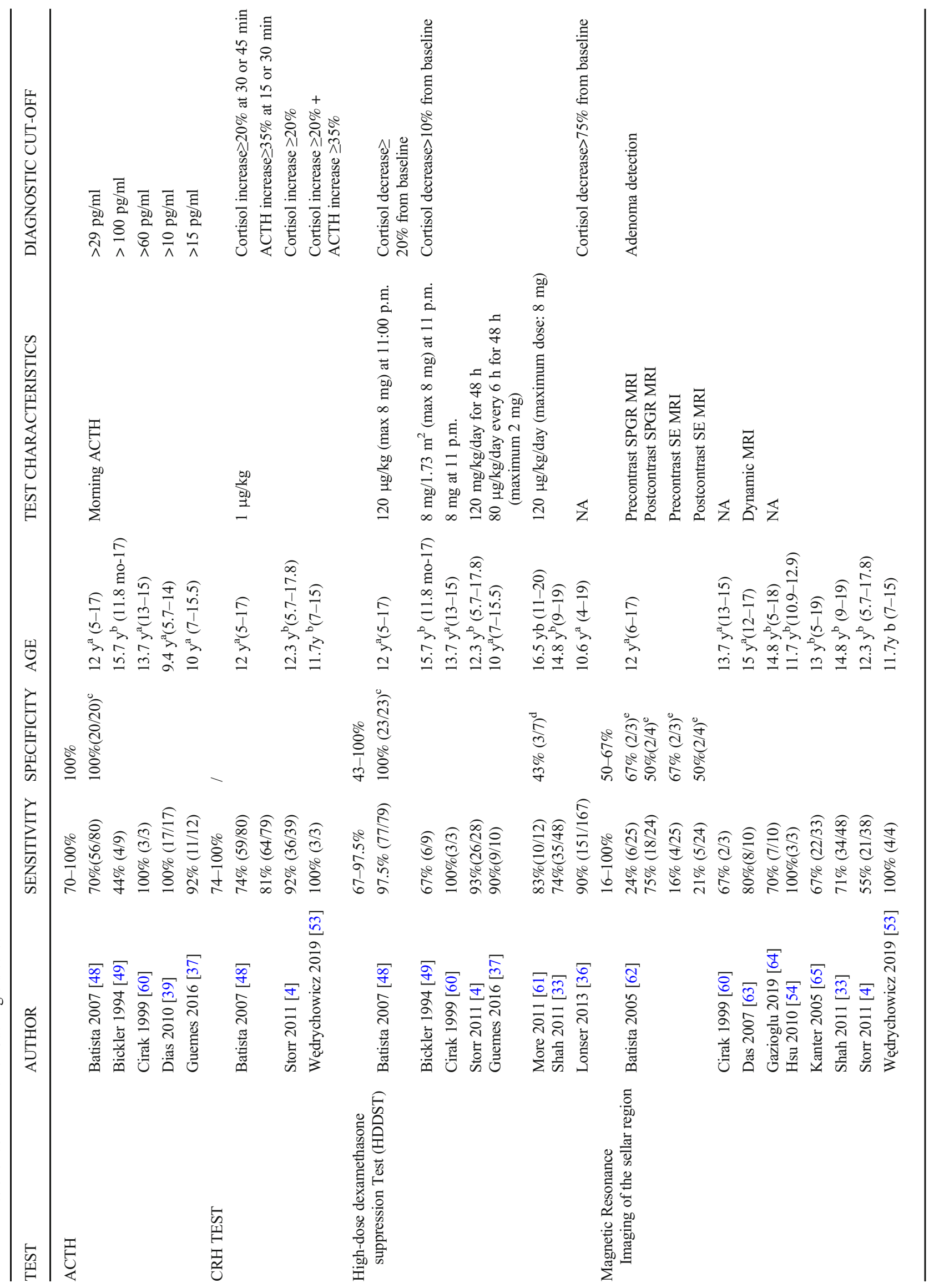


Storr et al. [4]. Pituitary MRI demonstrated less macroadenomas in paediatric $2 \%(1 / 41)$ compared with $15 \%(28 / 183)$ of adult patients $(P=0.04)$. The appearances were consistent with a microadenoma in $55 \%(21 / 38)$ of paediatric patients compared with $76 \%(50 / 66)$ of adult patients $(P=0.045)$. The percentage concordance of the microadenoma position by imaging compared with the findings at TSS was also lower in children $(34 \%, 13 / 38)$ compared with adults $(57 \%, 27 / 47)(P=0.058)$.

Consequently, a positive MRI is beneficial and supports the diagnosis of $\mathrm{CD}$ and adenoma identification, but the relatively low prediction rate requires the option of more precise adenoma localisation using bilateral inferior petrosal sinus sampling (BIPSS).

\subsection{Bilateral inferior petrosal sinus sampling (BIPSS)}

Preoperative BIPPS with CRH stimulation $(1 \mu \mathrm{g} / \mathrm{kg}$, max $100 \mu \mathrm{g}$ ) has been suggested in paediatric patients when there is a negative pituitary MRI with confirmed ACTH-dependent hypercortisolism [8]. However, the technique of BIPSS will not have been established in paediatric institutions and should be performed only by experienced radiologists in dedicated centres. Sedation during BIPSS is routinely not required, although general anaesthesia may be necessary in the youngest patients [39]. BIPSS is generally not necessary for confirmation of a pituitary tumour in patients with a positive MRI and biochemical features of $\mathrm{CD}$, because the incidence of incidentalomas in children is minimal [69, 70]. Ectopic ACTH secretion in children is also extremely rare, so the primary aim of BIPSS is to provide the localisation of the microadenoma by demonstrating lateralisation of ACTH secretion. In the largest series of paediatric CD patients, simultaneous BIPSS, with a basal central-to-peripheral ratio $>2$ and $>3$ after CRH injection, had a sensitivity of 76-99\% for the diagnosis of $\mathrm{CD}[4,8,36,39]$. Using the ACTH interpetrosal ratio $>1.4$, the sensitivity to detect lateralisation of an adenoma in the largest series of patients with paediatric $\mathrm{CD}$ (>20 cases) was $60-88 \%[4,8,36]$.

\subsection{Cavernous sinus sampling (CSS)}

CSS has been proposed as an alternative to BIPSS to improve the diagnostic accuracy in the differential diagnosis and localisation of pituitary adenomas. CSS is an invasive technique, which requires general anaesthesia and heparinisation. To date, only one small study reported CSS in paediatric patients, showing a sensitivity of $100 \%$ [64].

\section{Treatment of paediatric Cushing's disease}

Up to now, no consensus guidelines, specifically for the treatment of paediatric $\mathrm{CD}$, have been published. However, in the 
2015 Endocrine Society Clinical Practice Guidelines on the treatment of $\mathrm{CS}$, data regarding paediatric $\mathrm{CD}$ were included. These guidelines can therefore be considered as the current standard of care for therapy [71]. In paediatric patients, normalisation of cortisol levels, reversal of hypercortisolismrelated signs and symptoms, and pituitary adenoma removal are the main treatment goals. In terms of removal of the primary source of excess ACTH secretion, selective adenomectomy through TSS is agreed to be the first-line treatment [72]. Pituitary RT aims to suppress excess ACTH secretion and to inactivate its source. Success of both these treatments will also reverse hypercortisolism and its symptoms [71, 72].

Two additional forms of therapy, namely medical therapy and bilateral adrenalectomy, will not target the primary cause, but can reverse hypercortisolism and the clinical features related to it. In cases of recurrence of hypercortisolism following TSS or external pituitary irradiation, repeat TSS, medical therapy or bilateral adrenalectomy are options for second-line treatment. In states of life-threatening acute and severe cortisol excess, the use of the cortisol-suppressive agent etomidate has been effective in controlling cortisol so that definitive treatment such as adrenalectomy can be performed. The above therapies with their indications, results and consequences, will be discussed individually below.

\subsection{Transsphenoidal pituitary surgery}

Mainly developed in the paediatric setting by Charles Wilson at the University of California, San Francisco, in the 1980s $[73,74]$, TSS with selective microadenomectomy is the firstline treatment in paediatric $\mathrm{CD}$, due to the high prevalence of corticotroph microadenomas $[4,68,71]$. If successful, this approach will result in complete tumour resection and disease remission [71]. However, this surgical technique is challenging, with relatively few pituitary surgeons having longstanding experience of operating in children. Some technical aspects warrant consideration, namely the anatomy of the sellar region varying with age, and the fact that the sphenoid bone, usually solid at birth, undergoes pneumatisation from age 2 years until adolescence, limiting the identification of bony landmarks necessary for safe surgery [75]. Also, the inter-carotid distance is usually shorter in children aged less than 7 years compared to adults. Finally, paediatric patients with skull base lesions, such as pituitary tumours, present specific anatomic variants, including shorter nare-sellar and vomer-clivus distances and smaller transsphenoidal angles [75].

Due to the specific features of paediatric pituitary surgery, TSS in CD paediatric patients should be performed in a small number of specialist centres with high surgical volumes and by neurosurgeons with TSS experience in children $[68,71]$. Total excision of a corticotroph adenoma results in immediate post-operative ACTH and cortisol deficiency [68]. Normal corticotroph cells surrounding the adenoma are suppressed and undergo morphological alterations known histologically as Crooke's change [68].

\subsubsection{Remission following TSS}

There is no international consensus on the definition of successful TSS outcome. It is generally agreed that the term 'remission' is more appropriate than 'cure' [71]. Remission is generally defined as morning serum cortisol values $<5 \mu \mathrm{g} /$ dL $(<138 \mathrm{nmol} / \mathrm{L})$ or urinary free cortisol (UFC) $<28$ $56 \mathrm{nmol} /$ day $(<10-20 \mu \mathrm{g} /$ day $)$ within 7 days of selective tumour resection [71].

Two series of TSS in paediatric CD patients used a strict criterion for remission, namely post-TSS serum cortisol of $<1 \mu \mathrm{g} / \mathrm{dL}[28 \mathrm{nmol} / \mathrm{L}]$ [40] or $<1.8 \mu \mathrm{g} / \mathrm{dL}[50 \mathrm{nmol} / \mathrm{L}$ ] [4] and reported remission rates of 100 and $69 \%$, respectively. Other series reported remission rates of 70-98\% [36, 76]. An Indian series of 48 patients reported an overall cure rate of $56 \%$ with $77 \%$ cure for microadenomas [33]. When the patients treated at the $\mathrm{NIH}$ were analysed according to ethnic group, a higher proportion of subjects of Hispanic/Latino or African-American background, experiencing more severe CD features at presentation, had lower rates of initial cure and higher recurrence (10 out of $35 \mathrm{AA} / \mathrm{HI}, 28.6 \%$ ) when compared to non-Hispanic white subjects ( 8 out of $78,10.3 \%, p=$ 0.024) [77]. Successful TSS for paediatric CD is, however, associated with pituitary hormone deficiencies. Results from the NIH demonstrated GHD in a significant proportion of cases [78].

A German personal series of 100 children with CD operated on using the trans-nasal approach has recently been reported [68]. Over a 30-year period from 1980 to 2009, remission rates of $100 \%$ from 1980 to 1995 and $98 \%$ from 1996 to 2009 were achieved (63).. In a further recent Italian series of 43 patients with paediatric $\mathrm{CD}$, a remission rate of $72.1 \%$ was reported [79]. The most common complication of TSS was post-operative diabetes insipidus, present in 5\% of subjects at discharge from neurosurgical care [36].

In summary, TSS is effective and safe first-line treatment for paediatric $\mathrm{CD}$, although disease persistence may occur in up to approximately $30 \%$ of treated patients, who require second-line therapy which can be re-operation (TSS), pituitary RT, medical therapy to control cortisol synthesis, or bilateral adrenalectomy.

\subsubsection{Endoscopic TSS}

Another modification of the TSS approach is the endoscopic technique, using either the trans-nasal or endonasal approach. This form of TSS appears to be less invasive than the classical sub-labial approach and is now the established technique of 
many pituitary surgeons for adult patients. In paediatric $\mathrm{CD}$, a British series of $6 \mathrm{CD}$ children aged 11 to 17 years reported that endoscopic endo-nasal TSS resulted in biochemical remission in 5 , with no recurrence reported after a mean follow-up of 55 months [80]. Transient diabetes insipidus occurred in 5/6 subjects. In a recent multicentre paediatric study from Italy and Turkey, $4 / 5$ patients with $\mathrm{CD}$ achieved remission, one needing repeat endoscopic TSS [81].

\subsubsection{Recovery of the hypothalamic-pituitary-adrenal (HPA) axis}

The adrenal insufficiency (AI) which follows complete removal of an ACTH-secreting adenoma requires physiological glucocorticoid replacement with hydrocortisone $8-12 \mathrm{mg} / \mathrm{m}^{2}$ / day, and may persist for many months. A recent study from the NIH looked at factors potentially influencing the duration of AI and recovery of the HPA axis [82]. In 102 paediatric CD patients who recovered adrenal function following post-TSS remission, the median time to recovery was 12.3 months with a range of 3-35 months. The only biochemical variable at diagnosis related to recovery time was UFC, in which higher pre-operative values were associated with a longer interval to recovery of normal adrenal function, assessed by standard ACTH stimulation testing. Previous reports on factors predicting recovery of the HPA axis have been inconsistent [72]. The NIH study also reported, for the first time in paediatric CD, a statistically significant relationship $(p=0.0342)$ between a shorter HPA axis recovery time, and the likelihood of recurrence of CD [82], as had been shown in adults [83]. All patients with recurrence of hypercortisolism had recovery of the axis by 15 months post-TSS.

\subsection{Pituitary radiotherapy (RT)}

As discussed above, a minority of children receiving TSS for paediatric $\mathrm{CD}$ will not achieve remission and second-line therapy is needed to prevent continuing hypercortisolism. External pituitary RT is a therapeutic option in such patients [71, 84]. Unlike evidence in adult CD patients, few reports are available in children. Considering that over $90 \%$ of paediatric $\mathrm{CD}$ patients have microadenomas $[4,68]$, conventional fractionated external RT has been used rather than other techniques. However, pituitary RT is not universally practised in children, largely related to concern about effects on cognitive function [36].

In paediatric $\mathrm{CD}$ patients, gamma knife stereotactic radiosurgery was reported in 24 patients aged 10 to 21 years from a multi-national study [85]. Although precise details of the adenomas are not given, 18/24 patients had previously been treated unsuccessfully with TSS and 8 had cavernous sinus invasion by the adenoma, suggesting that these were not typical corticotroph microadenomas. Remission of the hypercortisolism occurred in $87.5 \%$ of subjects after a mean interval of 12 months with $20 \%$ developing new pituitary hormone deficiencies related to the RT. [85]

The rapid response of corticotroph adenomas to external RT was first documented in 1977 [86]. In 1985, external RT was delivered to 8 paediatric patients using a stereotactic technique delivering 50-70 Gy and inducing remission in $88 \%$ [87]. These findings were confirmed in a report from London in 7 patients, treated by a 6-MV linear accelerator delivering a dose of 45 Gy in 25 fractions over 35 days [88]. Remission from hypercortisolaemia occurred at a mean interval of 0.94 years (range $0.25-2.86$ ) [88]. In a subsequent Indian paediatric series of 8 patients, external RT induced a $50 \%$ remission rate, with 2 further patients having dexamethasone-suppressible cortisol at 26 months postirradiation [89]. RT therefore takes several months to be effective and medical therapy such as ketoconazole will be required to control hypercortisolism until circulating cortisol decreases to within the physiological range $[72,88]$.

\subsubsection{Pituitary function following radiotherapy}

Anterior pituitary hormone deficiencies may occur following pituitary RT for CD [71, 72, 84]. Therefore, long-term pituitary function should be monitored and investigated. However, the degree of individual hormone deficiencies is variable. Short-term GHD occurred most commonly [85-87, 89], being present in $86 \%$ of patients reported by Storr et al. Follow-up for a mean period of 10 years in the same patients showed that $3 / 4$ boys regained normal $\mathrm{GH}$ secretion (Peak $\mathrm{GH}>10 \mathrm{ng} / \mathrm{ml}$ ) [46]. It may be incorrect to attribute anterior pituitary deficiencies to RT alone because TSS induces GHD [78]. The longterm follow-up of 20 patients treated by TSS $(n=15)$ or $\mathrm{TSS}+\mathrm{RT}(n=5)$ for a mean interval of 10.6 years showed some recovery of GH secretion, but with $44 \%$ having longterm adult GHD [47]. Gonadotrophin deficiency was also present in 9/20 subjects causing impaired pubertal development and 4 requiring sex steroid replacement post-puberty [47].

\subsection{Medical treatment}

Medical treatment aimed at reducing circulating cortisol is usually a second-line therapy or potential first-line treatment in patients unwilling or unable to undergo TSS or pituitary RT [71, 72]. Medical therapy aims to suppress adrenal steroidogenesis and can be divided into potential long-term therapy such as ketoconazole, mitotane and metyrapone and shorterterm therapy such as etomidate. There are no substantive paediatric studies on cabergoline, mifepristone, osilodrostat or pasireotide.

Ketoconazole impairs adrenal and gonadal steroidogenesis by inhibiting side-chain cleavage, 17,20-lyase, and 11- $\beta$ 
hydroxylase enzymes. There are anecdotal reports in children, but but no definitive trial has been published. The main indications for ketoconazole are when awaiting TSS, after unsuccessful TSS, and during the period after RT and before normalisation of cortisol. A recent French report described treatment of 9 paediatric CD patients with 'low-dose' mitotane (titrated from $1 \mathrm{~g} /$ day to normalise UFC levels) [90]. After 12 months of therapy, height velocity and BMI SD scores improved significantly with changes comparable to those seen in 13 matched subjects in remission following TSS. Mitotane improved some features of $\mathrm{CD}$ but without perfect control of hypercortisolism. The adverse effects included digestive symptoms, weakness and AI, which were dose-dependent, making this therapy largely inappropriate for long-term therapy in children [90]. Monitoring of cortisol levels is also problematic.

There are acute clinical situations, such as the association of severe hypercortisolaemia with complications such as respiratory failure or acute psychosis, where rapid control of cortisol secretion is necessary in order to allow emergency therapy such as bilateral adrenalectomy. Intravenous etomidate infusions administered in an intensive care environmentat doses ranging from 1 to $3.5 \mathrm{mg} / \mathrm{h}$ have been documented to be effective in suppressing hypercortisolaemia in three paediatric $\mathrm{CD}$ patients $[44,46,91]$.

\subsection{Bilateral adrenalectomy}

Bilateral adrenalectomy is an important therapeutic option which may be life-saving and should be considered when first-line therapy is not available or when the clinical state of the patient does not allow TSS or pituitary RT, or when medical therapy fails to control hypercortisolaemia [71]. Adrenalectomy will eliminate hypercortisolaemia and reverse related complications rapidly [92]. However, it requires lifelong replacement with glucocorticoid and mineralocorticoid therapy and does not remove the primary cause of $\mathrm{CD}$, which remains in situ as a corticotroph adenoma $[5,72]$.

\subsection{Nelson's syndrome}

Nelson's syndrome may occur after bilateral adrenalectomy and is defined as MRI evidence of macroscopic ( $>1 \mathrm{~cm})$ corticotroph tumour enlargement associated with increasing levels of ACTH causing hyperpigmentation [93]. Consequently, after bilateral adrenalectomy, paediatric patients require regular evaluation using pituitary MRIs and ACTH levels.

There are anecdotal reports of Nelson's syndrome following bilateral adrenalectomy in children with CD [47] but few published series. In 6 children who underwent adrenalectomy between 8 and 17 years of age, 4 developed Nelson's syndrome at 2, 6, 10, and 12 years post-adrenalectomy. A review of the literature showed that in 37 patients with Nelson's syndrome, the mean age at diagnosis of $\mathrm{CD}$ was 12 years, with a mean interval of 8.4 years post-adrenalectomy [94]. In an earlier study, 31 patients aged from 10 months to 16 years underwent bilateral adrenalectomy for $\mathrm{CD}$ and postadrenalectomy hyperpigmentation was reported in 18 patients with sella enlargement in 8 patients (25\%) 1 to 5.5 years postadrenalectomy [95]. Consequently, Nelson's syndrome is a genuine risk in the paediatric age range and life-long followup is necessary. Nelson's syndrome, if it occurs, should be managed according to current adult endocrine practice [71, 96].

\section{Recurrence of Cushing's disease after remission}

There have been few studies which have formally looked at paediatric recurrence. Follow-up data after TSS and remission suggested that recurrence of hypercortisolism was uncommon $[4,32]$. Yordanova et al. studied long-term follow-up of 21 paediatric $\mathrm{CD}$ cases in remission following definitive therapy. The recurrence rate was $14.3 \%$ occurring from 2 to 7.6 years after primary treatment [47]. The large series of patients treated at the NIH $(n=72)$ has been studied for short-term and long-term remission and recurrence of $\operatorname{CD}[32,36]$. Children who remained in remission following TSS had significantly lower morning ACTH and cortisol levels compared with those who relapsed. Also, during a CRH stimulation test, ACTH and cortisol values were higher in patients who relapsed compared with those in remission. Relapse was associated with lack of histological confirmation of an adenoma, normal serum cortisol or ACTH and a normal response to CRH [32]. An expanded data-set of the NIH patients $(n=200)$ was reported by Lonser et al. in 2013, of whom 179 were available for longer term analysis. At 5 years post-TSS, $96.7 \%$ and at 10 years $90.5 \%$ were free of recurrence [36]. The study also associated long-term remission with younger age, smaller adenoma, and morning serum cortisol of $<1 \mu \mathrm{g} / \mathrm{dL}$ after surgery [36]. The current recurrence rate of paediatric patients treated at the NIH is $11.5 \%$ at a median of 44 months (range: 6.397 months) after TSS [82].

\section{Complications after induction of remission}

\subsection{Linear growth}

In patients experiencing growth failure due to endogenous hypercortisolism, achievement of target height during postsurgical remission depends on several hormonal and clinical factors. Elements limiting catch-up growth are onset of $\mathrm{CD}$ 
during puberty [34], advanced bone age [97] and the presence of vertebral fractures.

GHD following TSS has been clearly demonstrated [78] and is also seen following external fractionated $[89,98]$ or stereotactic [87] pituitary RT. Adult height in CD patients in remission is significantly below target height $[99,100]$. We advocate testing for GHD 3 months into biochemical remission with a low threshold for GH replacement therapy [55]. Although no controlled data are available, the combined use of GH and GnRH analogues in patients with GHD and severe short stature during puberty in order to delay bone age progression supports this therapeutic approach [55, 101].

\subsection{Long-term pituitary function}

GHD lasting for several years and persisting into adult life has been reported after successful therapy of CD using TSS or pituitary RT. [98] The degree of GHD was variable, being more severe in subjects with additional anterior pituitary deficiencies [98]. The long-term effects of successful pituitary RT were reported in 6 male subjects. At a mean of 1.0 year $(0.11-$ 2.54) after RT, 5 subjects (84\%) had GHD with peak GH $<10 \mathrm{ng} / \mathrm{ml}$, but when reassessed at a mean of 9.3 years $(7.6-$ 11.3) after RT, $75 \%$ had normal GH secretion, i.e. Peak GH $>9.6 \mathrm{ng} / \mathrm{ml}$. Other anterior pituitary functions in $5 / 6$ patients were normal on follow-up. All the six patients had testicular volumes of $20-25 \mathrm{ml}$ at the age of $14.5-28.5$ years [102]. A longer-term follow-up was reported in 21 patients, some also included in the previous report, after a mean interval from definitive treatment of 10.6 years (2.9-27.2) [47]. Gonadotropin deficiency caused impaired pubertal development in 9 patients (43\%), 4 requiring sex steroid replacement post-puberty and 4 patients (19\%) had more than one pituitary hormone deficiency, 3 after TSS and one after RT. Pituitary deficiencies at diagnosis and during remission of $\mathrm{CD}$ are described in Table 4.

\subsection{Body composition: Body mass index and bone mineral density}

Paediatric patients with CD show increased body weight and BMI at diagnosis [4]. In a study of 59 patients with CS due to multiple aetiologies from the NIH, BMI decreased to normal by 1 year following successful definitive therapy [106]. However, in patients with CS presenting around the age of adolescence, BMI remained elevated, notably in female patients [103]. Elevated BMI after remission was reported in a 15 -year-old patient who was followed for 6 years after remission and body composition was compared to that of her normal co-twin [107] with total body fat, abdominal visceral fat, and subcutaneous fat (\%) being 42,10 , and 41 in the $\mathrm{CD}$ subject versus 26,4 , and 17 in the normal twin. In $14 \mathrm{CD}$ patients followed to adult height after biochemical remission
BMI SDS was $+1 \cdot 7(0 \cdot 4-6 \cdot 2)$, being decreased compared to diagnosis $(P<0.05)$ but remaining greater than the normal population $(\mathrm{P}<0 \cdot 01)$ [55].

Osteoporosis is a common complication in paediatric $\mathrm{CD}$, affecting trabecular bone more severely than cortical bone [108]. Results have shown a significant increase in bone mineral density (BMD) during remission. In 14 subjects with $\mathrm{CD}$ followed for a minimum of 3 years post-remission, BMD and apparent density (BMAD) SDS at the lumbar spine (LS) at diagnosis were -1.8 and -1.25 , respectively, and after 3 years of follow-up approached the mean with no further increase apparent up to 7 years of follow-up [103]. Whereas hip BMD SDS increased from -1.3 at diagnosis to -0.40 at 3 years and 0 at 7 years of follow-up, femoral neck BMAD remained at or around 0 SDS at diagnosis and during follow-up [103].

In children with $\mathrm{CD}$, vertebral BMD was more severely affected than femoral BMD being independent of the degree or duration of hypercortisolism. Lumbar spine BMD improved significantly after TSS [109]. Deficits in BMD and serum osteocalcin levels in childhood-onset $\mathrm{CD}$ patients were partly, but not completely, reversed 2 years after normalisation of cortisol levels, although longer recovery times or additive therapy, such as bisphosphonates, may be necessary to maximize peak bone mass in children and adolescents [105]. Auxology data before and after treatment are shown in Table 4.

\subsection{Blood pressure, metabolic variables and psychological status}

Detailed studies on blood pressure (BP) have been performed at the NIH [106]. Approximately half of children and adolescents with CD develop hypertension [4]. The role of hypercortisolism in the pathogenesis of hypertension and its reversibility was studied in 31 hypertensive children and adolescents with CS of various aetiologies before and for a period of 1 year after surgical cure [106]. Preoperatively, $45 \%$ of these patients presented with an increase of mean BP. Following normalisation of cortisol, systolic BP remained increased in $30.7 \%, 15.8 \%$, and $5.5 \%$ of patients at 3,6 , and 12 months respectively whereas diastolic and mean BP normalised by 3 months after surgical cure. A significant, positive correlation was observed between the systolic BP and the duration of the disease, pointing towards the deleterious effects of prolonged hypercortisolism. The normalisation of BP within a year from the correction of hypercortisolism suggests that, in general, young patients with $\mathrm{CD}$ do not develop essential hypertension [106]. However, in approximately $4 \%$ of patients, residual hypertension persisted after normalisation of cortisol [110].

Studies in metabolic parameters have shown a significant improvement in biochemical variables, such as fasting glucose, fasting insulin, HOMA index and lipid profile during remission [111]. As described above, central obesity is likely 


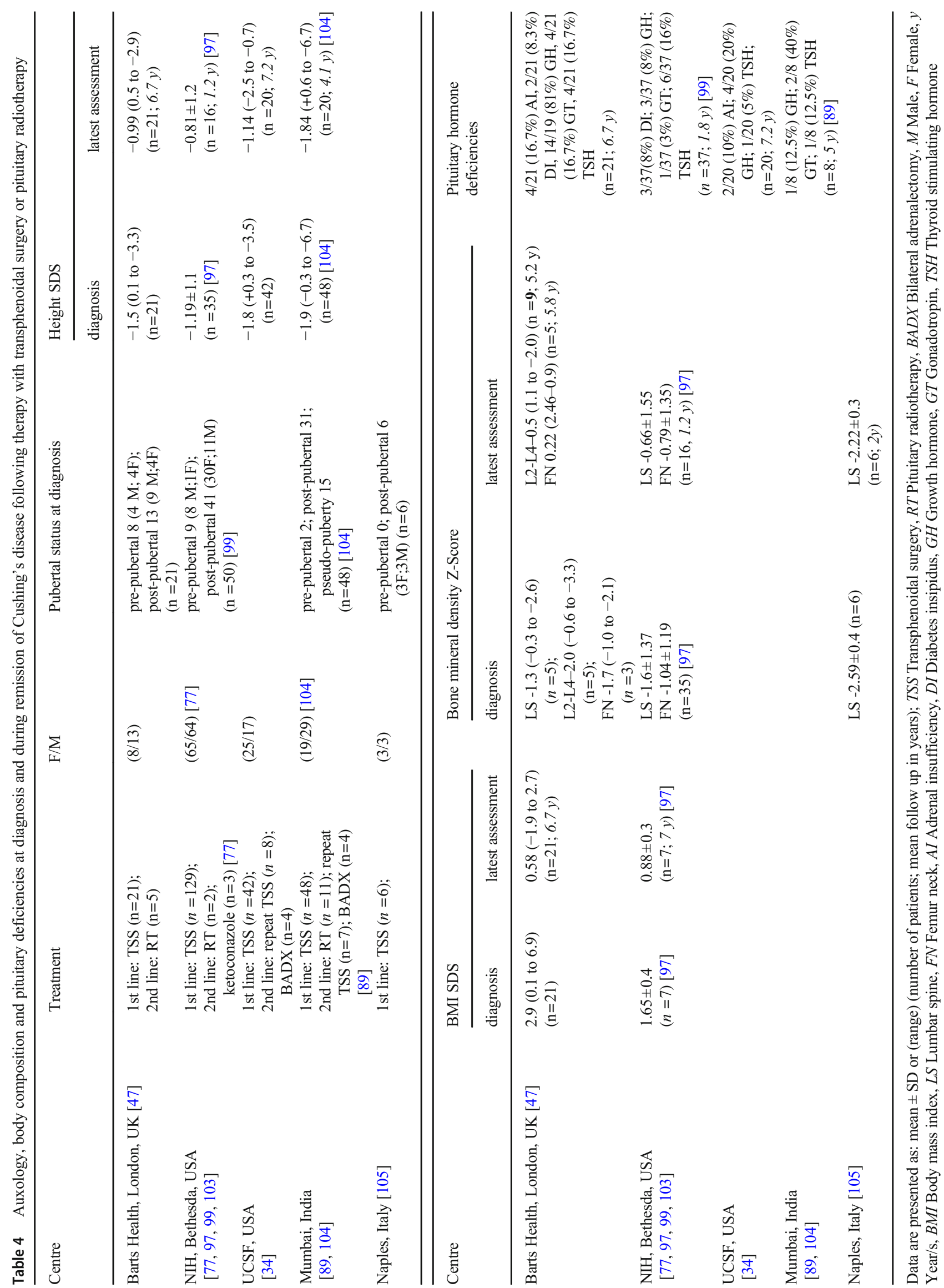


to persist with a positive correlation reported between waist circumference and fasting insulin 1 year after remission [111].

Psychological abnormalities and decreased quality of life contribute to the complex symptomatology of paediatric CD. The association between hypercortisolism and abnormalities in hippocampal volume and cognitive function has been described, although it is not clear to what extent this applies to children with CD [112]. However, cerebral atrophy has been documented in paediatric $\mathrm{CD}$ and although this improves rapidly during remission, decreased cognitive function and school performance were still evident 1 year after successful remission [113]. Specific psychological disturbances have recently been described in children after surgical cure of CS. These include behavioural changes such as anger-rage outbursts and affective symptoms such as suicidal ideation, anxiety and depression [114]. Clearly, the central nervous and psychological effects of prolonged hypercortisolism are potentially profound and awareness of their possible occurrence forms part of the long-term management of $\mathrm{CD}$ in remission.

\section{Conclusions}

The rarity of paediatric $\mathrm{CD}$ presents challenges in referral and diagnosis because the pathological nature of the clinical features may not be recognised until they are extreme. By that time morbidity affecting growth, puberty, body composition, bone mineral density and psychological status may be established and difficult to reverse. The importance of early diagnosis reflects the urgency of controlling hypercortisolism to prevent further complications. As mentioned above, close consultation between paediatric and adult endocrinologists is strongly recommended to optimise clinical care. Therapeutic options are essentially the same as for adult $\mathrm{CD}$, however the choice of a pituitary surgeon with experience of TSS in children is essential. Even in the best hands, post-surgical remission in all patients is unlikely and opinions on second-line therapy are likely to vary between countries and institutions. Paediatric CD patients, managed in experienced units, have a good prognosis, although on-going challenges in terms of normalisation of disturbed growth, pituitary function, BMI, BMD and psychological problems may remain. The possibility of recurrence of hypercortisolism will necessitate longterm follow-up with eventual transition to a specialist adult endocrine department.

Authors' contributions MM, PM, RF, SC and VH researched the literature for paper inclusion and completed the first draft, MOS structured the review, AMI, AG, HS, MCDM and MOS, performed the interim review and MCDM and MOS edited the text and revised the final manuscript.

Funding Not applicable.

Data availability Not applicable.

\section{Compliance with ethical standards}

Conflicts of interest/competing interest VH, MM, PM, RF, SC, MCDM have nothing to disclose. AMI has served as a consultant in the advisory boards for Novartis, Takeda, Recordati, and Sandoz and has received unconditional research grants from Shire, IPSEN, and Pfizer.

Ethics approval Not applicable.

Consent to participate Not applicable.

Consent for publication Not applicable.

Code availability Not applicable.

Open Access This article is licensed under a Creative Commons Attribution 4.0 International License, which permits use, sharing, adaptation, distribution and reproduction in any medium or format, as long as you give appropriate credit to the original author(s) and the source, provide a link to the Creative Commons licence, and indicate if changes were made. The images or other third party material in this article are included in the article's Creative Commons licence, unless indicated otherwise in a credit line to the material. If material is not included in the article's Creative Commons licence and your intended use is not permitted by statutory regulation or exceeds the permitted use, you will need to obtain permission directly from the copyright holder. To view a copy of this licence, visit http://creativecommons.org/licenses/by/4.0/.

\section{References}

1. Newell-Price J, Bertagna X, Grossman AB, Nieman LK. Cushing's syndrome. Lancet. 2006;367(9522):1605-17. https:// doi.org/10.1016/s0140-6736(06)68699-6.

2. Ragnarsson O, Olsson DS, Chantzichristos D, Papakokkinou E, Dahlqvist P, Segerstedt E, et al. The incidence of Cushing's disease: a nationwide Swedish study. Pituitary. 2019;22(2):179-86. https://doi.org/10.1007/s11102-019-00951-1.

3. Reincke M, Sbiera S, Hayakawa A, Theodoropoulou M, Osswald A, Beuschlein F, et al. Mutations in the deubiquitinase gene USP8 cause Cushing's disease. Nat Genet. 2015;47(1):31-8. https://doi. org/10.1038/ng.3166.

4. Storr HL, Alexandraki KI, Martin L, Isidori AM, Kaltsas GA, Monson JP, et al. Comparisons in the epidemiology, diagnostic features and cure rate by transsphenoidal surgery between paediatric and adult-onset Cushing's disease. Eur J Endocrinol. 2011;164(5):667-74. https://doi.org/10.1530/EJE-10-1120.

5. Sharma ST, Nieman LK, Feelders RA. Cushing's syndrome: epidemiology and developments in disease management. Clin Epidemiol. 2015;7:281-93. https://doi.org/10.2147/CLEP. S44336.

6. Lindholm J, Juul S, Jorgensen JO, Astrup J, Bjerre P, FeldtRasmussen $U$, et al. Incidence and late prognosis of cushing's syndrome: a population-based study. J Clin Endocrinol Metab. 2001;86(1):117-23. https://doi.org/10.1210/jcem.86.1.7093.

7. Etxabe J, Vazquez JA. Morbidity and mortality in Cushing's disease: an epidemiological approach. Clin Endocrinol (Oxf). 1994;40(4):479-84. https://doi.org/10.1111/j.1365-2265.1994. tb02486.x.

8. Batista D, Gennari M, Riar J, Chang R, Keil MF, Oldfield EH, et al. An assessment of petrosal sinus sampling for localization of pituitary microadenomas in children with Cushing disease. J Clin 
Endocrinol Metab. 2006;91(1):221-4. https://doi.org/10.1210/jc. 2005-1096.

9. Nieman LK, Ilias I. Evaluation and treatment of Cushing's syndrome. Am J Med. 2005;118(12):1340-6. https://doi.org/10.1016/ j.amjmed.2005.01.059.

10. Magiakou MA, Chrousos GP. Cushing's syndrome in children and adolescents: current diagnostic and therapeutic strategies. J Endocrinol Invest. 2002;25(2):181-94. https://doi.org/10.1007/ BF03343985.

11. Storr HL, Chan LF, Grossman AB, Savage MO. Paediatric Cushing's syndrome: epidemiology, investigation and therapeutic advances. Trends Endocrinol Metab. 2007;18(4):167-74. https:// doi.org/10.1016/j.tem.2007.03.005.

12. Stratakis CA. Cushing syndrome in pediatrics. Endocrinol Metab Clin North Am. 2012;41(4):793-803. https://doi.org/10.1016/j. ec1.2012.08.002.

13. Kunwar S, Wilson CB. Pediatric pituitary adenomas. J Clin Endocrinol Metab. 1999;84(12):4385-9. https://doi.org/10.1210/ jcem.84.12.6240.

14. Pasternak-Pietrzak K, Moszczynska E, Jurkiewicz E, Szalecki M. Paediatric Cushing's disease - a literature review of epidemiology, pathogenesis, clinical symptoms, and diagnostics. Endokrynol Pol. 2020;71(1):87-95. https://doi.org/10.5603/EP.a2019.0040.

15. Herman V, Fagin J, Gonsky R, Kovacs K, Melmed S. Clonal origin of pituitary adenomas. J Clin Endocrinol Metab. 1990;71(6):1427-33. https://doi.org/10.1210/jcem-71-6-1427.

16. Cuny T, Pertuit M, Sahnoun-Fathallah M, Daly A, Occhi G, Odou MF, et al. Genetic analysis in young patients with sporadic pituitary macroadenomas: besides AIP don't forget MEN1 genetic analysis. Eur J Endocrinol. 2013;168(4):533-41. https://doi.org/ 10.1530/EJE-12-0763.

17. Castinetti F, Morange I, Conte-Devolx B, Brue T. Cushing's disease. Orphanet J Rare Dis. 2012;7:41. https://doi.org/10.1186/ 1750-1172-7-41.

18. Thakker RV, Newey PJ, Walls GV, Bilezikian J, Dralle H, Ebeling PR, et al. Clinical practice guidelines for multiple endocrine neoplasia type 1 (MEN1). J Clin Endocrinol Metab. 2012;97(9):2990-3011. https://doi.org/10.1210/jc.2012-1230.

19. Stratakis CA, Tichomirowa MA, Boikos S, Azevedo MF, Lodish $\mathrm{M}$, Martari M, et al. The role of germline AIP, MEN1, PRKAR1A, CDKN1B and CDKN2C mutations in causing pituitary adenomas in a large cohort of children, adolescents, and patients with genetic syndromes. Clin Genet. 2010;78(5):457-63. https://doi.org/10.1111/j.1399-0004.2010.01406.x.

20. Tichomirowa MA, Barlier A, Daly AF, Jaffrain-Rea ML, Ronchi C, Yaneva M, et al. High prevalence of AIP gene mutations following focused screening in young patients with sporadic pituitary macroadenomas. Eur J Endocrinol. 2011;165(4):509-15. https:// doi.org/10.1530/EJE-11-0304.

21. Perez-Rivas LG, Theodoropoulou M, Ferrau F, Nusser C, Kawaguchi K, Stratakis CA, et al. The gene of the ubiquitinspecific protease 8 is frequently mutated in adenomas causing Cushing's disease. J Clin Endocrinol Metab. 2015;100(7):E9971004. https://doi.org/10.1210/jc.2015-1453.

22. Faucz FR, Tirosh A, Tatsi C, Berthon A, Hernandez-Ramirez LC, Settas N, et al. Somatic USP8 gene mutations are a common cause of pediatric Cushing disease. J Clin Endocrinol Metab. 2017;102(8):2836-43. https://doi.org/10.1210/jc.2017-00161.

23. Ma ZY, Song ZJ, Chen JH, Wang YF, Li SQ, Zhou LF, et al. Recurrent gain-of-function USP8 mutations in Cushing's disease. Cell Res. 2015;25(3):306-17. https://doi.org/10.1038/cr.2015.20.

24. Cohen M, Persky R, Stegemann R, Hernández-Ramírez LC, Zeltser D, Lodish MB, et al. Germline USP8 mutation associated with pediatric Cushing disease and other clinical features: a new syndrome. JCEM. 2019;104(10):4676-82. https://doi.org/10. 1210/jc.2019-00697.
25. Albani A, Theodoropoulou M, Reincke M. Genetics of Cushing's disease. Clin Endocrinol (Oxf). 2018;88(1):3-12. https://doi.org/ 10.1111/cen.13457.

26. Chen J, Jian X, Deng S, Ma Z, Shou X, Shen Y, et al. Identification of recurrent USP48 and BRAF mutations in Cushing's disease. Nat Commun. 2018;9(1):3171. https://doi. org/10.1038/s41467-018-05275-5.

27. Roussel-Gervais A, Bilodeau S, Vallette S, Berthelet F, Lacroix A, Figarella-Branger D, et al. Cooperation between cyclin E and p27(Kip1) in pituitary tumorigenesis. Mol Endocrinol. 2010;24(9):1835-45. https://doi.org/10.1210/me.2010-0091.

28. Hernandez-Ramirez LC, Gam R, Valdes N, Lodish MB, Pankratz $\mathrm{N}$, Balsalobre A, et al. Loss-of-function mutations in the CABLES1 gene are a novel cause of Cushing's disease. Endocr Relat Cancer. 2017;24(8):379-92. https://doi.org/10.1530/ERC17-0131.

29. Jordan S, Lidhar K, Korbonits M, Lowe DG, Grossman AB. Cyclin D and cyclin E expression in normal and adenomatous pituitary. Eur J Endocrinol. 2000;143(1):R1-6. https://doi.org/ 10.1530/eje.0.143r001.

30. Yaneva M, Vandeva S, Zacharieva S, Daly AF, Beckers A. Genetics of Cushing's syndrome. Neuroendocrinology. 2010;92(Suppl 1):6-10. https://doi.org/10.1159/000314215.

31. Chasseloup F, Pankratz N, Lane J, Faucz FR, Keil MF, Chittiboina P, et al. Germline CDKN1B Loss-of-Function Variants Cause Pediatric Cushing's Disease With or Without an MEN4 Phenotype. J Clin Endocrinol Metab. 2020;105(6). https:// doi.org/10.1210/clinem/dgaa160.

32. Batista DL, Oldfield EH, Keil MF, Stratakis CA. Postoperative testing to predict recurrent Cushing disease in children. J Clin Endocrinol Metab. 2009;94(8):2757-65. https://doi.org/10.1210/ jc.2009-0302.

33. Shah NS, George J, Acharya SV, Lila AR, Sarathi V, Bandgar TR, et al. Cushing disease in children and adolescents: twenty years' experience in a tertiary care center in India. Endocr Pract. 2011;17(3):369-76. https://doi.org/10.4158/EP10143.OR.

34. Devoe DJ, Miller WL, Conte FA, Kaplan SL, Grumbach MM, Rosenthal SM, et al. Long-term outcome in children and adolescents after transsphenoidal surgery for Cushing's disease. J Clin Endocrinol Metab. 1997;82(10):3196-202. https://doi.org/10. 1210/jcem.82.10.4290.

35. Libuit LG, Karageorgiadis AS, Sinaii N, Nguyen May NM, Keil MF, Lodish MB, et al. A gender-dependent analysis of Cushing's disease in childhood: pre- and postoperative follow-up. Clin Endocrinol (Oxf). 2015;83(1):72-7. https://doi.org/10.1111/cen. 12644.

36. Lonser RR, Wind JJ, Nieman LK, Weil RJ, DeVroom HL, Oldfield EH. Outcome of surgical treatment of 200 children with Cushing's disease. J Clin Endocrinol Metab. 2013;98(3):892-901. https://doi.org/10.1210/jc.2012-3604.

37. Guemes M, Murray PG, Brain CE, Spoudeas HA, Peters CJ, Hindmarsh PC, et al. Management of Cushing syndrome in children and adolescents: experience of a single tertiary Centre. Eur J Pediatr. 2016;175(7):967-76. https://doi.org/10.1007/s00431016-2727-5.

38. Storr HL, Isidori AM, Monson JP, Besser GM, Grossman AB, Savage MO. Prepubertal Cushing's disease is more common in males, but there is no increase in severity at diagnosis. J Clin Endocrinol Metab. 2004;89(8):3818-20. https://doi.org/10.1210/ jc.2003-031531.

39. Dias RP, Kumaran A, Chan LF, Martin L, Afshar F, Matson M, et al. Diagnosis, management and therapeutic outcome in prepubertal Cushing's disease. Eur J Endocrinol. 2010;162(3):603-9. https://doi.org/10.1530/EJE-09-0509.

40. Magiakou MA, Mastorakos G, Oldfield EH, Gomez MT, Doppman JL, Cutler GB Jr, et al. Cushing's syndrome in children 
and adolescents. Presentation, diagnosis, and therapy. N Engl J Med. 1994;331(10):629-36. https://doi.org/10.1056/ NEJM199409083311002.

41. Pecori Giraldi F, Moro M, Cavagnini F. Study group on the Hypothalamo-pituitary-adrenal Axis of the Italian Society of E. gender-related differences in the presentation and course of Cushing's disease. J Clin Endocrinol Metab. 2003;88(4):1554-8. https://doi.org/10.1210/jc.2002-021518.

42. Storr HL, Savage MO. Management of endocrine disease: Paediatric Cushing's disease. Eur J Endocrinol. 2015;173(1): R35-45. https://doi.org/10.1530/EJE-15-0013.

43. Peters CJ, Ahmed ML, Storr HL, Davies KM, Martin LJ, Allgrove $\mathrm{J}$, et al. Factors influencing skeletal maturation at diagnosis of paediatric Cushing's disease. Horm Res. 2007;68(5):231-5. https://doi.org/10.1159/000101336.

44. Greening JE, Brain CE, Perry LA, Mushtaq I, Sales Marques J, Grossman AB, et al. Efficient short-term control of hypercortisolaemia by low-dose etomidate in severe paediatric Cushing's disease. Horm Res. 2005;64(3):140-3. https://doi.org/ $10.1159 / 000088587$.

45. Dupuis CC, Storr HL, Perry LA, Ho JT, Ahmed L, Ong KK, et al. Abnormal puberty in paediatric Cushing's disease: relationship with adrenal androgen, sex hormone binding globulin and gonadotrophin concentrations. Clin Endocrinol (Oxf). 2007;66(6):83843. https://doi.org/10.1111/j.1365-2265.2007.02822.x.

46. Chan LF, Vaidya M, Westphal B, Allgrove J, Martin L, Afshar F, et al. Use of intravenous etomidate to control acute psychosis induced by the hypercortisolaemia in severe paediatric Cushing's disease. Horm Res Paediatr. 2011;75(6):441-6. https://doi.org/10. $1159 / 000324419$

47. Yordanova G, Martin L, Afshar F, Sabin I, Alusi G, Plowman NP, et al. Long-term outcomes of children treated for Cushing's disease: a single center experience. Pituitary. 2016;19(6):612-24. https://doi.org/10.1007/s11102-016-0756-8.

48. Batista DL, Riar J, Keil M, Stratakis CA. Diagnostic tests for children who are referred for the investigation of Cushing syndrome. Pediatrics. 2007;120(3):e575-e86. https://doi.org/10. 1542/peds.2006-2402.

49. Bickler SW, McMahon TJ, Campbell JR, Mandel S, Piatt JH, Harrison MW. Preoperative diagnostic evaluation of children with Cushing's syndrome. J Pediatr Surg. 1994;29(5):671-6. https:// doi.org/10.1016/0022-3468(94)90738-2.

50. Gafni RI, Papanicolaou DA, Nieman LK. Nighttime salivary cortisol measurement as a simple, noninvasive, outpatient screening test for Cushing's syndrome in children and adolescents. J Pediatr. 2000;137(1):30-5. https://doi.org/10.1067/mpd.2000.106226.

51. Leinung MC, Kane LA, Scheithauer BW, Carpenter PC, Laws ER Jr, Zimmerman D. Long term follow-up of transsphenoidal surgery for the treatment of Cushing's disease in childhood. J Clin Endocrinol Metab. 1995;80(8):2475-9. https://doi.org/10.1210/ jcem.80.8.7629245.

52. Shapiro L, Elahi S, Riddoch F, Perry LA, Martin L, Akker SA, et al. Investigation for Paediatric Cushing's syndrome using twenty-four-hour urinary free cortisol determination. Horm Res Paediatr. 2016;86(1):21-6. https://doi.org/10.1159/000446913.

53. Wedrychowicz A, Hull B, Tyrawa K, Kalicka-Kasperczyk A, Zielinski G, Starzyk J. Cushing disease in children and adolescents - assessment of the clinical course, diagnostic process, and effects of the treatment - experience from a single paediatric Centre. Pediatr Endocrinol Diabetes Metab. 2019;25(3):127-43. https://doi.org/10.5114/pedm.2019.87179.

54. Hsu P-Y, Tung Y-C, Lee C-T, Lo F-S, Wu M-Z, Tsai W-Y, et al. Cushing's disease in children: report of three cases. Pediatr Neonatol. 2010;51(5):303-7. https://doi.org/10.1016/s18759572(10)60059-9.
55. Davies JH, Storr HL, Davies K, Monson JP, Besser GM, Afshar F, et al. Final adult height and body mass index after cure of paediatric Cushing's disease. Clin Endocrinol (Oxf). 2005;62(4):46672. https://doi.org/10.1111/j.1365-2265.2005.02244.x.

56. Martinelli CE Jr, Sader SL, Oliveira EB, Daneluzzi JC, Moreira AC. Salivary cortisol for screening of Cushing's syndrome in children. Clin Endocrinol (Oxf). 1999;51(1):67-71. https://doi.org/10. 1046/j.1365-2265.1999.00749.x.

57. Hodes A, Lodish MB, Tirosh A, Meyer J, Belyavskaya E, Lyssikatos C, et al. Hair cortisol in the evaluation of Cushing syndrome. Endocrine. 2017;56(1):164-74. https://doi.org/10. 1007/s12020-017-1231-7.

58. Legro RS, Lin HM, Demers LM, Lloyd T. Urinary free cortisol increases in adolescent caucasian females during perimenarche. $\mathrm{J}$ Clin Endocrinol Metab. 2003;88(1):215-9. https://doi.org/10. 1210/jc.2002-020256.

59. Dias R, Storr HL, Perry LA, Isidori AM, Grossman AB, Savage MO. The discriminatory value of the low-dose dexamethasone suppression test in the investigation of paediatric Cushing's syndrome. Horm Res. 2006;65(3):159-62. https://doi.org/10.1159/ 000091830.

60. Cirak B, Palaoglu S, Akalan N. Clinical and therapeutic properties of Cushing's disease in childhood. Pediatr Neurosurg. 1999;31(1): 12-5. https://doi.org/10.1159/000028825.

61. More J, Young J, Reznik Y, Raverot G, Borson-Chazot F, Rohmer $\mathrm{V}$, et al. Ectopic ACTH syndrome in children and adolescents. J Clin Endocrinol Metab. 2011;96(5):1213-22. https://doi.org/10. 1210/jc.2010-2276.

62. Batista D, Courkoutsakis NA, Oldfield EH, Griffin KJ, Keil M, Patronas NJ, et al. Detection of adrenocorticotropin-secreting pituitary adenomas by magnetic resonance imaging in children and adolescents with Cushing disease. J Clin Endocrinol Metab. 2005;90(9):5134 40. https://doi.org/10.1210/jc.2004-1778.

63. Das NK, Lyngdoh BT, Bhakri BK, Behari S, Bhatia V, Jain VK, et al. Surgical management of pediatric Cushing's disease. Surg Neurol. 2007;67(3):251-7; discussion 7. https://doi.org/10.1016/j. surneu.2006.05.067.

64. Gazioglu N, Canaz H, Camlar M, Tanriover N, Kocer N, Islak C, et al. Neurosurgical treatment of Cushing disease in pediatric patients: case series and review of literature. Childs Nerv Syst. 2019;35(11):2127-32. https://doi.org/10.1007/s00381-018-40135 .

65. Kanter AS, Diallo AO, Jane JA Jr, Sheehan JP, Asthagiri AR, Oskouian RJ, et al. Single-center experience with pediatric Cushing's disease. J Neurosurg. 2005;103(5 Suppl):413-20. https://doi.org/10.3171/ped.2005.103.5.0413.

66. Nieman LK, Biller BM, Findling JW, Newell-Price J, Savage MO, Stewart PM, et al. The diagnosis of Cushing's syndrome: an Endocrine Society clinical practice guideline. J Clin Endocrinol Metab. 2008;93(5):1526-40. https://doi.org/10.1210/jc.20080125.

67. Peters CJ, Storr HL, Grossman AB, Savage MO. The role of corticotrophin-releasing hormone in the diagnosis of Cushing's syndrome. Eur J Endocrinol. 2006;155(suppl_1):S93-S8. https:// doi.org/10.1530/eje.1.02238.

68. Crock PA, Ludecke DK, Knappe UJ, Saeger W. A personal series of 100 children operated for Cushing's disease (CD): optimizing minimally invasive diagnosis and transnasal surgery to achieve nearly $100 \%$ remission including reoperations. J Pediatr Endocrinol Metab. 2018;31(9):1023-31. https://doi.org/10.1515/ jpem-2018-0262.

69. Abunimer AM, Abou-Al-Shaar H, Azab MA, Karsy M, Guan J, Kestle JR, et al. Transsphenoidal approaches for microsurgical resection of pituitary adenomas in pediatric patients. World Neurosurg. 2019;123:e186-e93. https://doi.org/10.1016/j.wneu. 2018.11.117. 
70. Pandey P, Ojha BK, Mahapatra AK. Pediatric pituitary adenoma: a series of 42 patients. J Clin Neurosci. 2005;12(2):124-7. https:// doi.org/10.1016/j.jocn.2004.10.003.

71. Nieman LK, Biller BM, Findling JW, Murad MH, Newell-Price J, Savage MO, et al. Treatment of Cushing's syndrome: an Endocrine Society clinical practice guideline. J Clin Endocrinol Metab. 2015;100(8):2807-31. https://doi.org/10.1210/jc.20151818.

72. Pivonello R, De Leo M, Cozzolino A, Colao A. The treatment of Cushing's disease. Endocr Rev. 2015;36(4):385-486. https://doi. org/10.1210/er.2013-1048.

73. Patel SK, Husain Q, Eloy JA, Couldwell WT, Liu JK. Norman Dott, Gerard Guiot, and Jules hardy: key players in the resurrection and preservation of transsphenoidal surgery. Neurosurg Focus. 2012;33(2):E6. https://doi.org/10.3171/2012.6. FOCUS12125.

74. Styne DM, Grumbach MM, Kaplan SL, Wilson CB, Conte FA. Treatment of Cushing's disease in childhood and adolescence by transsphenoidal microadenomectomy. N Engl J Med. 1984;310(14):889-93. https://doi.org/10.1056/ NEJM198404053101405.

75. Marino AC, Taylor DG, Desai B, Jane JA Jr. Surgery for pediatric pituitary adenomas. Neurosurg Clin N Am. 2019;30(4):465-71. https://doi.org/10.1016/j.nec.2019.05.008.

76. Dyer EH, Civit T, Visot A, Delalande O, Derome P. Transsphenoidal surgery for pituitary adenomas in children. Neurosurgery. 1994;34(2):207-12; discussion 12. https://doi. org/10.1227/00006123-199402000-00001.

77. Gkourogianni A, Sinaii N, Jackson SH, Karageorgiadis AS, Lyssikatos C, Belyavskaya E, et al. Pediatric Cushing disease: disparities in disease severity and outcomes in the Hispanic and African-American populations. Pediatr Res. 2017;82(2):272-7. https://doi.org/10.1038/pr.2017.58.

78. Magiakou MA, Mastorakos G, Gomez MT, Rose SR, Chrousos GP. Suppressed spontaneous and stimulated growth hormone secretion in patients with Cushing's disease before and after surgical cure. J Clin Endocrinol Metab. 1994;78(1):131-7. https://doi.org/ 10.1210/jcem.78.1.7507118.

79. Barzaghi LR, Losa M, Capitanio JF, Albano L, Weber G, Mortini P. Pediatric pituitary adenomas: early and long-term surgical outcome in a series of 85 consecutive patients. Neurosurgery. 2019;85(1):65-74. https://doi.org/10.1093/neuros/nyy204.

80. Storr HL, Drake WM, Evanson J, Matson M, Berney DM, Grossman AB, et al. Endonasal endoscopic transsphenoidal pituitary surgery: early experience and outcome in paediatric Cushing's disease. Clin Endocrinol (Oxf). 2014;80(2):270-6. https://doi.org/10.1111/cen.12275.

81. Locatelli D, Veiceschi P, Castelnuovo P, Tanriover N, Evliyaoglu $\mathrm{O}$, Canaz H, et al. Transsphenoidal surgery for pituitary adenomas in pediatric patients: a multicentric retrospective study. Childs Nerv Syst. 2019;35(11):2119-26. https://doi.org/10.1007/ s00381-019-04179-z.

82. Tatsi C, Neely M, Flippo C, Bompou ME, Keil M, Stratakis CA. Recovery of hypothalamic-pituitary-adrenal Axis in pediatric Cushing disease. Clin Endocrinol (Oxf). 2020;94:40-7. https:// doi.org/10.1111/cen.14300.

83. Alexandraki KI, Kaltsas GA, Isidori AM, Storr HL, Afshar F, Sabin I, et al. Long-term remission and recurrence rates in Cushing's disease: predictive factors in a single-centre study. Eur J Endocrinol. 2013;168(4):639-48. https://doi.org/10.1530/EJE12-0921.

84. Estrada J, Boronat M, Mielgo M, Magallon R, Millan I, Diez S, et al. The long-term outcome of pituitary irradiation after unsuccessful transsphenoidal surgery in Cushing's disease. N Engl J Med. 1997;336(3):172-7. https://doi.org/10.1056/ NEJM199701163360303.
85. Shrivastava A, Mohammed N, Xu Z, Liscak R, Kosak M, Krsek $\mathrm{M}$, et al. Outcomes after gamma knife stereotactic radiosurgery in pediatric patients with Cushing disease or acromegaly: a multiinstitutional study. World Neurosurg. 2019;125:e1104-e13. https://doi.org/10.1016/j.wneu.2019.01.252.

86. Jennings AS, Liddle GW, Orth DN. Results of treating childhood Cushing's disease with pituitary irradiation. N Engl J Med. 1977;297(18):957-62. https://doi.org/10.1056/ NEJM197711032971801.

87. Thoren M, Rahn T, Hallengren B, Kaad PH, Nilsson KO, Ravn H, et al. Treatment of Cushing's disease in childhood and adolescence by stereotactic pituitary irradiation. Acta Paediatr Scand. 1986;75(3):388-95. https://doi.org/10.1111/j.1651-2227.1986. tb10219.x.

88. Storr HL, Plowman PN, Carroll PV, Francois I, Krassas GE, Afshar F, et al. Clinical and endocrine responses to pituitary radiotherapy in pediatric Cushing's disease: an effective second-line treatment. J Clin Endocrinol Metab. 2003;88(1):34-7. https://doi. org/10.1210/jc.2002-021032.

89. Acharya SV, Gopal RA, Goerge J, Menon PS, Bandgar TR, Shah NS. Radiotherapy in paediatric Cushing's disease: efficacy and long term follow up of pituitary function. Pituitary. 2010;13(4): 293-7. https://doi.org/10.1007/s11102-010-0231-x.

90. Motte E, Rothenbuhler A, Gaillard S, Lahlou N, Teinturier C, Coutant R, et al. Mitotane (op'DDD) restores growth and puberty in nine children with Cushing's disease. Endocr Connect. 2018;7(12):1280-7. https://doi.org/10.1530/EC-18-0215.

91. Mettauer N, Brierley J. A novel use of etomidate for intentional adrenal suppression to control severe hypercortisolemia in childhood. Pediatr Crit Care Med. 2009;10(3):e37-40. https://doi.org/ 10.1097/PCC.0b013e318198b096.

92. McArthur RG, Hayles AB, Salassa RM. Childhood Cushing disease: results of bilateral adrenalectomy. J Pediatr. 1979;95(2): 214-9. https://doi.org/10.1016/s0022-3476(79)80654-x.

93. Barber TM, Adams E, Ansorge O, Byrne JV, Karavitaki N, Wass JA. Nelson's syndrome. Eur J Endocrinol. 2010;163(4):495-507. https://doi.org/10.1530/EJE-10-0466.

94. Thomas CG Jr, Smith AT, Benson M, Griffith J. Nelson's syndrome after Cushing's disease in childhood: a continuing problem. Surgery. 1984;96(6):1067-77.

95. Hopwood NJ, Kenny FM. Incidence of Nelson's syndrome after adrenalectomy for Cushing's disease in children: results of a nationwide survey. Am J Dis Child. 1977;131(12):1353-6. https:// doi.org/10.1001/archpedi.1977.02120250035005.

96. Fountas A, Lim ES, Drake WM, Powlson AS, Gurnell M, Martin NM, et al. Outcomes of Patients with Nelson's Syndrome after Primary Treatment: A Multicenter Study from 13 UK Pituitary Centers. J Clin Endocrinol Metab. 2020;105(5). https://doi.org/ 10.1210/clinem/dgz200.

97. Lodish MB, Gourgari E, Sinaii N, Hill S, Libuit L, Mastroyannis $\mathrm{S}$, et al. Skeletal maturation in children with Cushing syndrome is not consistently delayed: the role of corticotropin, obesity, and steroid hormones, and the effect of surgical cure. J Pediatr. 2014;164(4):801-6. https://doi.org/10.1016/j.jpeds.2013.11.065.

98. Carroll PV, Monson JP, Grossman AB, Besser GM, Plowman PN, Afshar F, et al. Successful treatment of childhood-onset Cushing's disease is associated with persistent reduction in growth hormone secretion. Clin Endocrinol (Oxf). 2004;60(2):169-74. https://doi. org/10.1046/j.1365-2265.2003.01922.x.

99. Magiakou MA, Mastorakos G, Chrousos GP. Final stature in patients with endogenous Cushing's syndrome. J Clin Endocrinol Metab. 1994;79(4):1082-5. https://doi.org/10.1210/jcem.79.4. 7962277.

100. Minnetti M, Caiulo S, Ferrigno R, Baldini-Ferroli B, Bottaro G, Gianfrilli D, et al. Abnormal linear growth in paediatric adrenal diseases: pathogenesis, prevalence and management. Clin 
Endocrinol (Oxf). 2020;92(2):98-108. https://doi.org/10.1111/ cen.14131.

101. Mericq MV, Eggers M, Avila A, Cutler GB Jr, Cassorla F. Near final height in pubertal growth hormone $(\mathrm{GH})$-deficient patients treated with GH alone or in combination with luteinizing hormone-releasing hormone analog: results of a prospective, randomized trial. J Clin Endocrinol Metab. 2000;85(2):569-73. https://doi.org/10.1210/jcem.85.2.6343.

102. Chan LF, Storr HL, Plowman PN, Perry LA, Besser GM, Grossman $\mathrm{AB}$, et al. Long-term anterior pituitary function in patients with paediatric Cushing's disease treated with pituitary radiotherapy. Eur J Endocrinol. 2007;156(4):477-82. https://doi. org/10.1530/EJE-06-0588.

103. Leong GM, Abad V, Charmandari E, Reynolds JC, Hill S, Chrousos GP, et al. Effects of child- and adolescent-onset endogenous Cushing syndrome on bone mass, body composition, and growth: a 7-year prospective study into young adulthood. J Bone Miner Res. 2007;22(1):110-8. https://doi.org/10.1359/jbmr. 061010.

104. Acharya SV, Gopal RA, Lila A, Menon PS, Bandgar TR, Shah NS. Bone age and factors affecting skeletal maturation at diagnosis of paediatric Cushing's disease. Pituitary. 2010;13(4):355-60. https://doi.org/10.1007/s11102-010-0246-3.

105. Di Somma C, Pivonello R, Loche S, Faggiano A, Klain M, Salvatore M, et al. Effect of 2 years of cortisol normalization on the impaired bone mass and turnover in adolescent and adult patients with Cushing's disease: a prospective study. Clin Endocrinol (Oxf). 2003;58(3):302-8. https://doi.org/10.1046/j.1365-2265. 2003.01713.x.

106. Magiakou MA, Mastorakos G, Zachman K, Chrousos GP. Blood pressure in children and adolescents with Cushing's syndrome before and after surgical care. J Clin Endocrinol Metab. 1997;82(6):1734-8. https://doi.org/10.1210/jcem.82.6.3985.

107. Abad V, Chrousos GP, Reynolds JC, Nieman LK, Hill SC, Weinstein RS, et al. Glucocorticoid excess during adolescence leads to a major persistent deficit in bone mass and an increase in central body fat. J Bone Miner Res. 2001;16(10):1879-85. https://doi.org/10.1359/jbmr.2001.16.10.1879.

108. Lukert BP, Raisz LG. Glucocorticoid-induced osteoporosis: pathogenesis and management. Ann Intern Med. 1990;112(5):352-64. https://doi.org/10.7326/0003-4819-112-5-352.

109. Lodish MB, Hsiao HP, Serbis A, Sinaii N, Rothenbuhler A, Keil MF, et al. Effects of Cushing disease on bone mineral density in a pediatric population. J Pediatr. 2010;156(6):1001-5. https://doi. org/10.1016/j.jpeds.2009.12.027.

110. Lodish MB, Sinaii N, Patronas N, Batista DL, Keil M, Samuel J, et al. Blood pressure in pediatric patients with Cushing syndrome. J Clin Endocrinol Metab. 2009;94(6):2002-8. https://doi.org/10. 1210/jc.2008-2694.

111. Keil MF, Graf J, Gokarn N, Stratakis CA. Anthropometric measures and fasting insulin levels in children before and after cure of Cushing syndrome. Clin Nutr. 2012;31(3):359-63. https://doi.org/ 10.1016/j.clnu.2011.11.007.

112. Frimodt-Moller KE, Mollegaard Jepsen JR, Feldt-Rasmussen U, Krogh J. Hippocampal volume, cognitive functions, depression, anxiety, and quality of life in patients with Cushing syndrome. J Clin Endocrinol Metab. 2019;104(10):4563-77. https://doi.org/ 10.1210/jc.2019-00749.

113. Merke DP, Giedd JN, Keil MF, Mehlinger SL, Wiggs EA, Holzer $\mathrm{S}$, et al. Children experience cognitive decline despite reversal of brain atrophy one year after resolution of Cushing syndrome. J Clin Endocrinol Metab. 2005;90(5):2531-6. https://doi.org/10. 1210/jc.2004-2488.

114. Keil MF, Zametkin A, Ryder C, Lodish M, Stratakis CA. Cases of Psychiatric Morbidity in Pediatric Patients After Remission of Cushing Syndrome. Pediatrics. 2016;137(4). https://doi.org/10. 1542/peds.2015-2234.

Publisher's note Springer Nature remains neutral with regard to jurisdictional claims in published maps and institutional affiliations. 